\title{
Consequences of Seed Priming with Salicylic Acid and Hydro Priming on Smooth Vetch Seedling Growth under Water Deficiency
}

\author{
Amin Namdari ${ }^{1} \&$ Abolfazl Baghbani ${ }^{2}$ \\ 1 Dryland Agricultural Research Institute, Agricultural Research Education and Extension Organization \\ (AREEO), Iran \\ ${ }^{2}$ Department of Agriculture Science, Payam Noor University, Tehran, Iran \\ Correspondence: Amin Namdari, Dryland Agricultural Research Institute, Agricultural Research Education and \\ Extension Organization (AREEO), Iran. Tel: 98-099-0930-9368. E-mail: aminnamdari1983@gmail.com
}

Received: September 24, 2017

Accepted: October 28, 2017

Online Published: November 15, 2017

doi:10.5539/jas.v9n12p259

URL: https://doi.org/10.5539/jas.v9n12p259

\begin{abstract}
Due to low rainfall at early autumn, smooth vetch seedling growth in rain-fed lands often is limited by water deficit stress yet the data regarding the reactions of smooth vetch to water deficit at early growth stages are pretty rare. The objective of current study was to examine possibility of using priming treatments (hydro priming and priming salicylic acid) to alleviate the inhibitory effect of water deficiency during early growth of Smooth Vetch. In this respect, seeds were soaked in distilled water (hydro priming) or $0.5 \mathrm{mM}$ solution of SA for $36 \mathrm{~h}$ at $10{ }^{\circ} \mathrm{C}$ then dried back to original moisture content. Pots were irrigated for 25 days at four levels of available water containing field capacity (FC), $75 \%$ FC, 50\% FC and 25\% FC. In general, seedling emergence and early growth were markedly limited by increasing water deficiency. However, priming treatments particularly with SA caused considerable improvement in either emergence or growth of seedlings (dry weight, length). The obtained results showed that primed samples exhibited higher accumulation of proline, glycine betaine (GB) under all levels of available water except $100 \% \mathrm{FC}$ and also higher total soluble sugars (TSS) and trehalose under severe water deficit ( $25 \%$ FC). SA primed samples had higher relative water content especially under higher levels of water deficiency. The more balanced water status within SA primed samples also was accompanied with higher accumulation of proline and glycine betaine. There were significant differences between two priming treatments in terms of proline and GB content within seedlings and SA priming considerably increased proline and GB accumulation. In contrast to proline and GB, TSS and trehalose content wasn't influenced by SA treatment and both hydro and SA primed samples showed statistically similar quantities.
\end{abstract}

Keywords: osmolytes, salicylic acid, seedling emergence, vetch, water deficit

\section{Introduction}

Vetch species including smooth vetch (Vicia dasycarpa) are cultivated in West and North West of Iran either as forage crop or as green manure. During the current decade, there has been an increasing trend to use vetch plants as a forage crop throughout dry lands in Iran. High forage quality and quantity, suitable adaption to a wide range of climatic conditions and also the ability to fix atmospheric nitrogen, make vetch species promising plants in rotation (Dabney et al., 2001). Since the cultivation of vetch species is mainly conducted in rain-fed lands, the germination and early growth of these plants often depends on early rainfall in autumn. Lack or shortage of rainfall during the early growth of vetch, which is rampant throughout the region, causes water stress and limits the seedling emergence, growth and consequently restrict the plant potential to produce sufficient forage or green manure yield.

In order to uptake water and nutrition from soil, osmotic potential within plants cells must be higher than soil. Plant cells under osmotic stress accumulate non-toxic compounds named compatible solutes or osmolytes to adjust osmotic potential within cytoplasm (Bartels \& Sunkar, 2005). Sugars, sugar alcohols, amino acids and glycine betaine, have been introduced as main plant osmolytes. Furthermore, currently it is proposed that osmolytes not only play critical role regarding osmotic adjustment but also have other physiological roles such as scavenging reactive oxygen species which is vital under osmotic stress (Chen \& Murata, 2002). In this respect, Fernandez et al. (2010) expressed that osmolytes along with osmotic homeostasis, are involved in maintaining of 
bio-membranes integrity and also ROS scavenging within plant cells. Accumulation of osmolytes has been reported as a main strategy adopted by plants to enhance osmotic stress tolerance (Grzesiak et al., 2013).

Seed priming process includes imbibition of seeds in water or solutions in order to start events related to germination followed by drying the seeds to their original moisture content before radicle emergence (Varier et al., 2010). Seed priming is one of the methods which is widely used to invigorate seeds for higher and more uniform germination, emergence especially under stress conditions (Hussian et al., 2014). It has been proved in many cases that adding special plant growth regulators to priming solution may improve performance of seed priming in terms of better germination and early growth under abiotic stresses (Alonso-Ramirez et al., 2009; Liu et al., 2011). Salicylic acid (SA) as a signal molecule contributes in induction of stress tolerance within plant cells (Horvath et al., 2007) and several studies proposed that SA play an important role in induction of defense mechanisms against abiotic stresses within plant cells (Szalai et al., 2011; Alonso-Ramırez et al., 2009; Shah, 2003).

In this regard, in current study we examined the possibility of using priming treatments with water (hydro priming) and salicylic acid to mitigate the harmful effects of water deficiency during early growth of Smooth Vetch seedlings. In addition, since osmotic adjustment has been introduced as a key mechanism which make plants capable to confront osmotic stress, we also measured some key osmolytes in plant species including proline, glycine betaine (GB), trehalose and total soluble sugars.

\section{Materials and Methods}

\subsection{Seed Material and Treatments}

Smooth Vetch (Vicia dasycarpa) seeds were collected from Institute of Dry-Land Researches, Maragheh, Iran. The experiment was conducted in research greenhouse, Agriculture College of Tehran University. The initial germination of seeds without stress was about 100 percent. Before conducting treatments, seeds were sterilized superficially in $5 \%$ bleach for $30 \mathrm{~s}$ then washed in distilled water. In order to seed priming, seeds were incubated in distilled water (hydro-priming) or $0.5 \mathrm{mM}$ salicylic acid for $36 \mathrm{~h}$ at $10{ }^{\circ} \mathrm{C}$ then withdrawn before radicle emergence. After priming, primed seeds were dried at lab temperature $\left(29^{\circ} \mathrm{C}\right)$ until their moisture content returned to the original level. Primed and non-primed seeds were seeded at $3 \mathrm{~cm}$ depth in plastic pots $(20 \times 20$ $\mathrm{cm}$ ) containing field soil with silty clay loam texture, electrical conductivity (EC):1.3 and pH: 7.7. Each pot contained 5 seeds and three replicates were carried out for each treatment. Seedlings grew in greenhouse at $20{ }^{\circ} \mathrm{C}$ (optimum temperature) for 25 days. The available water treatments were conducted based on portion of filed capacity (FC) included, 100 (control), 75, 50 and 25\% field capacity (FC). In order to adjusting available water, the pots were consistently weighted to determine the amount required water for each treatment. Seedling emergence and early growth variables were recorded after 25 days.

\subsection{Water Status}

In order to measure leaf relative water content (RWC) the method described by Scholander et al. (1955) was performed. RWC was determined as: $\mathrm{RWC}=\left(\mathrm{W}_{\mathrm{f}}-\mathrm{W}_{\mathrm{d}}\right) /\left(\mathrm{W}_{\mathrm{s}}-\mathrm{W}_{\mathrm{D}}\right) \times 100 \%$. $\mathrm{W}_{\mathrm{f}}$ : sample fresh weight, $\mathrm{W}_{\mathrm{d}}$ : sample dry weight, $\mathrm{W}_{\mathrm{s}}$ : sample saturated weight.

\subsection{Osmolytes Measurement}

Total soluble sugars (TSS) content was measured according to phenol- sulfuric acid procedure (Zhang, 1993). Trehalose content determination was carried out by the method of Trevelyan and Harrison (1956). In brief, samples were homogenized in $80 \%$ ethanol then a centrifuge at $5000 \mathrm{~g}$ was conducted for $10 \mathrm{~min} .0 .1 \mathrm{~mL}$ TCA was added to supernatant. $4 \mathrm{~mL}$ of anthron reagent was added to reaction mixture and eventually the absorbance at $620 \mathrm{~nm}$ was recorded through spectrophotometer. The results expressed as $\mu$ gram per gram of dry matter. To determine seedlings glycine betaine content the procedure used by Grieve and Grattan (1983) was performed. Briefly, $0.5 \mathrm{mg}$ of well dried seedling samples were shaken in deionized water for about 2 days at $25{ }^{\circ} \mathrm{C}$ to obtain extracts. After filtering, the extracts were mixed with the same volume of $2 \mathrm{~N} \mathrm{H}_{2} \mathrm{SO}_{4}$ and the $50 \mathrm{~mL}$ of the mixture was measured in centrifuge tubes and cooled in ice bath for 1 hour. Then $0.2 \mathrm{~mL}$ of cold potassium iodide-iodine $\left(\mathrm{KI}_{-} \mathrm{I}_{2}\right)$ reagent was added and tubes were stored for 16 hours at $0 \mathrm{C}$. subsequently, a centrifuge at $10000 \mathrm{~g}$ was conducted and supernatant separated. Then The crystals were dissolved in $9 \mathrm{~mL}$ of 1,2 dichloroethan. Eventually, absorbance at $365 \mathrm{~nm}$ was recorded by spectrophotometer. The content of proline was determined according to the well-known method of acid-ninhydrin as proceeded by Bates et al. (1973).

\subsection{Statistical Analysis}

The current experiment was carried out on base of completely randomized block design in 3 replications with 12 treatments within each replication. The results are presented as average data $\pm \mathrm{SD}(n=3)$. Analysis of variance 
were conducted by using SPSS (19 version) and graphs, were drawn by Microsoft Excel. The Differences among means were statistically analyzed using Duncan test at $5 \%$ probability level $(\mathrm{P} \leq 0.05)$.

\section{Results}

\subsection{Seedling Emergence and Growth}

Seedling growth (dry weight) and emergence consistently declined when water deficit increased (Table 1). The influence of water deficit on suppressing seedling growth and emergence varied considerably dependent on seed priming treatments. Seed priming substantially improved both variables (Table 1). The efficiency of priming treatments (with or without SA) regarding seedling growth and emergence, increased under higher levels of water deficit (50 and $25 \%$ FC). Furthermore, SA priming caused significant increase in seedling growth and emergence under all soil available water levels apart from control (100\% FC). Root and shoot length were affected by water deficit in different patterns. While root length increased under lower available water (except for $25 \%$ FC), shoot length consistently decreased by more severe water deficit levels. Both root and shoot lengths reached to minimum level under $25 \%$ FC priming treatments significantly raised root and shoot lengths. Seed priming with SA led to greater root and shoot lengths compared with hydro priming especially under lower levels of soil available water.

Table 1. The impact of seed priming treatments under different available water levels on smooth vetch's seedling emergence, early growth and relative water content (RWC). The data are average $\pm \mathrm{SD}(n=3)$. The same letters within each column mean no significant difference between compared data at $\mathrm{P} \leq 0.05$ probability level

\begin{tabular}{llllll}
\hline Treatment & $\begin{array}{l}\text { Seedling emergence } \\
(\%)\end{array}$ & $\begin{array}{l}\text { Seedling dry weight } \\
(\mathrm{mg})\end{array}$ & $\begin{array}{l}\text { Shoot length } \\
(\mathrm{cm})\end{array}$ & $\begin{array}{l}\text { Root length } \\
(\mathrm{cm})\end{array}$ & $\begin{array}{l}\text { RWC } \\
(\%)\end{array}$ \\
\hline FC & $94 \pm 4.35 \mathrm{a}$ & $25.36 \pm 0.38 \mathrm{a}$ & $22.72 \pm 0.28 \mathrm{~b}$ & $16.33 \pm 0.4 \mathrm{de}$ & $88.73 \pm 2.92 \mathrm{a}$ \\
$75 \%$ FC & $82.5 \pm 3.21 \mathrm{bc}$ & $23.41 \pm 0.66 \mathrm{~b}$ & $21.23 \pm 0.28 \mathrm{c}$ & $16.51 \pm 0.49 \mathrm{de}$ & $82.54 \pm 1.84 \mathrm{c}$ \\
$50 \%$ FC & $50.25 \pm 3.05 \mathrm{e}$ & $18.67 \pm 0.58 \mathrm{~d}$ & $15.49 \pm 0.26 \mathrm{f}$ & $17.49 \pm 0.23 \mathrm{bc}$ & $73.47 \pm 3.44 \mathrm{~d}$ \\
$25 \%$ FC & $22 \pm 3.03 \mathrm{f}$ & $11.23 \pm 0.65 \mathrm{~g}$ & $10.61 \pm 0.34 \mathrm{~h}$ & $14.12 \pm 0.48 \mathrm{f}$ & $42.41 \pm 1.17 \mathrm{f}$ \\
HP + FC & $95.6 \pm 2.083 \mathrm{a}$ & $25.89 \pm 0.29 \mathrm{a}$ & $23.31 \pm 0.54 \mathrm{a}$ & $16.56 \pm 0.26 \mathrm{de}$ & $88.24 \pm 2.73 \mathrm{a}$ \\
HP + 75\% FC & $87.5 \pm 2.64 \mathrm{~b}$ & $24.21 \pm 0.6 \mathrm{~b}$ & $23.04 \pm 0.37 \mathrm{a}$ & $17.1 \pm 0.21 \mathrm{~cd}$ & $83.71 \pm 2.26 \mathrm{bc}$ \\
HP + 50\% FC & $66.25 \pm 3.21 \mathrm{~d}$ & $20.12 \pm 0.77 \mathrm{c}$ & $17.93 \pm 0.43 \mathrm{~d}$ & $17.71 \pm 0.34 \mathrm{ab}$ & $79.31 \pm 1.8 \mathrm{c}$ \\
HP + 25\%FC & $46.25 \pm 4.72 \mathrm{e}$ & $13.34 \pm 0.44 \mathrm{f}$ & $12.56 \pm 0.34 \mathrm{~g}$ & $16.26 \pm 0.28 \mathrm{e}$ & $58.24 \pm 3.56 \mathrm{e}$ \\
SA+ FC & $97.33 \pm 2.51 \mathrm{a}$ & $26.71 \pm .58 \mathrm{a}$ & $23.89 \pm 0.57 \mathrm{a}$ & $17.43 \pm 0.47 \mathrm{bc}$ & $88.81 \pm 0.96 \mathrm{a}$ \\
SA+75\% FC & $96 \pm 1.52 \mathrm{a}$ & $26.06 \pm .26 \mathrm{a}$ & $23.54 \pm 0.59 \mathrm{a}$ & $17.56 \pm 0.31 \mathrm{bc}$ & $87.14 \pm 0.74 \mathrm{ab}$ \\
SA + 50\%FC & $79.5 \pm 4.5 \mathrm{c}$ & $22.34 \pm 0.86 \mathrm{c}$ & $20.91 \pm 0.31 \mathrm{c}$ & $18.59 \pm 0.35 \mathrm{a}$ & $81.46 \pm 2.53 \mathrm{c}$ \\
SA + 25\%FC & $64.25 \pm 3.05 \mathrm{~d}$ & $17.21 \pm 0.39 \mathrm{e}$ & $16.14 \pm 0.33 \mathrm{e}$ & $17.51 \pm 0.34 \mathrm{bc}$ & $67.57 \pm 2.74 \mathrm{~d}$ \\
\hline
\end{tabular}

Note. HP: hydro priming, SA: priming with salicylic acid, FC: field capacity.

\subsection{Seedling Water Status}

Predictably, relative water content (RWC) was negatively affected by water deficiency (Table 1). However RWC declined under lower available water in all treatments regardless the sort of priming treatment, yet SA primed samples showed the lowest decline rate followed by hydro and non-primed ones. The severe water deficiency ( $25 \%$ FC) compared with control condition reduced RWC by close to 52, 35 and $24 \%$ respectively for non-priming, hydro priming and SA priming treatments. Obviously, seed priming especially with SA, had a substantial positive effect on seedling water maintenance under severe water deficiency.

\section{3-3 Osmolytes Accumulation}

Soluble sugars within primed and non-primed samples increased under lower soil moistures apart from $25 \% \mathrm{FC}$ (Figure 1). The level of soluble sugars slightly declined when water deficit increased from $50 \%$ FC to $25 \%$ FC. As shown in Figure 1, seed priming (either with water or with SA) caused significant rise in soluble sugars under all levels of soil moisture apart from $25 \% \mathrm{FC}$ hydro priming increased the level of soluble sugars more than SA priming treatment except at $75 \% \mathrm{FC}$ however the differences were not statistically significant (standard deviations have been shown in Figure 1). 


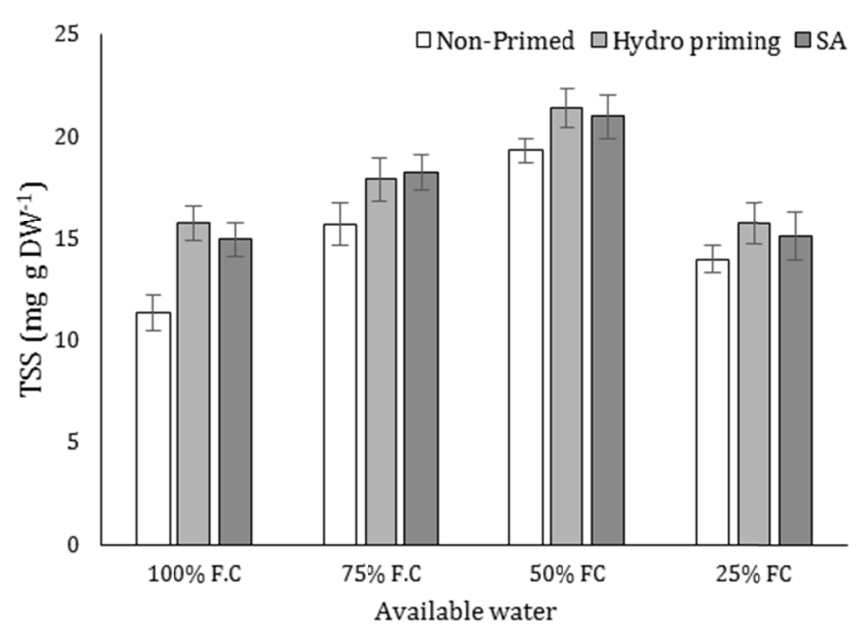

Figure 1. Influence of seed priming treatments on total soluble sugars (TSS) accumulation within 25 days smooth vetch seedlings under different levels of available water

Note. SA: priming with salisylic acid, FC: field capacity.

Trehalose content within seedlings increased under higher levels of water deficit ( 75,50 and $25 \% \mathrm{FC})$. Figure 1 and Figure 2 showed that hydro priming increased trehalose more than SA under all water treatment except at $75 \% \mathrm{FC}$ however the differences were not statistically significant (standard deviations have been shown in Figure 2).

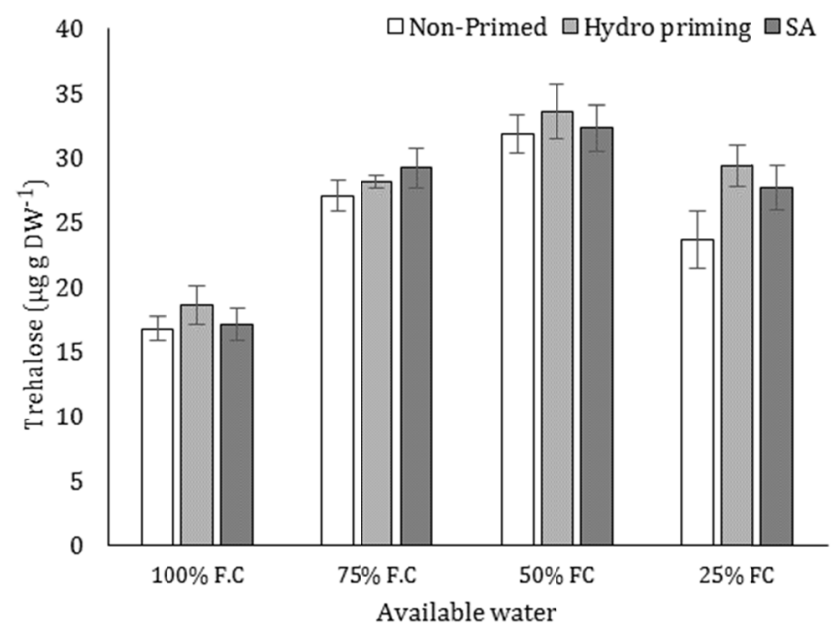

Figure 2. Influence of seed priming treatments on trehalose accumulation within 25 days smooth vetch seedlings under different levels of available water

Note. SA: priming with salisylic acid, FC: field capacity.

Generally, as water deficiency increased, the proline content within all treatments raised significantly regardless the sort of seed priming (Figure 3). The impact of more severe levels of water deficit (50 and $25 \% \mathrm{FC}$ ) on proline content within seedlings were remarkable. In terms of priming treatments, as shown in Figure 3, under all soil available water levels, particularly 50 and $25 \%$ FC, seed priming with SA caused marked increase in proline accumulation compared with other treatments while hydro primed seeds exhibited their advantage only against non-primed seeds when available water fell to $50 \%$ of FC and even lower (25\% FC). 


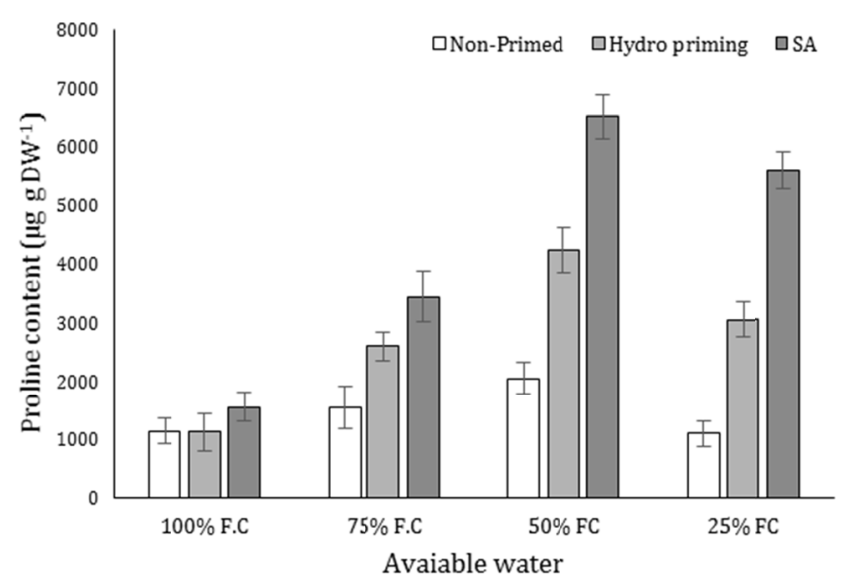

Figure 3. Influence of seed priming treatments on proline accumulation within 25 days smooth vetch seedlings under different levels of available water.

Note. SA: priming with salisylic acid, FC: field capacity.

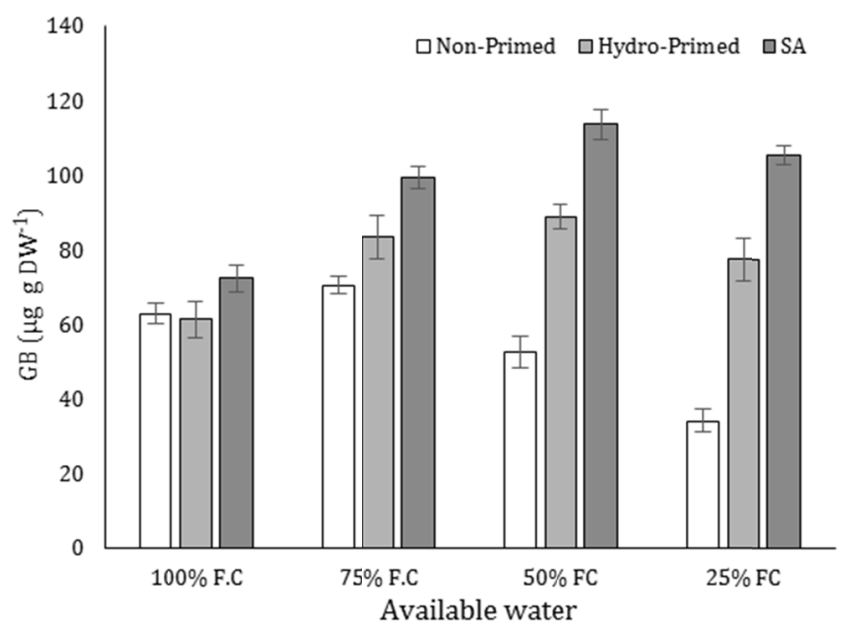

Figure 4. Influence of seed priming treatments on Glycine betaine (GB) accumulation within 25 days smooth vetch seedlings under different levels of available water.

Note. SA: priming with salisylic acid, FC: field capacity.

GB accumulation within seedlings was significantly induced by water deficit level (Figure 4). Seedlings contained higher amount of GB under more severe water deficit however there was a slight reduction when water deficit approached 25\% FC. Under all levels of soil moisture except $100 \%$ FC, primed samples accumulated greater amounts of GB within seedlings. The differences between two priming treatments were significant under 75,50 and $25 \%$ FC. Seed priming with SA compared with hydro priming, caused considerable increase in GB accumulation and this advantage extended under more severe water stress (Figure 4).

\section{Discussion}

\subsection{Seedling Emergence and Growth}

Early growth of vetch seedlings in autumn is a key growth stage which determines forage yield potential especially under rain-fed conditions. If the emergence and early growth be limited by sub-optimal environmental factors including low available water, the vulnerable stages of plant growth such as flowering, might be affected by late season heat and/or drought stresses in dry-land regions. Seedling growth may be inhibited or postponed due to water stress since water stress creates low osmotic potential in which water uptake by seed will be disturbed (Kaya et al., 2006). Parera and Cantliffe (1994) expressed that seedling emergence is a key stage to reach the potential of quantitative, qualitative yield in annual crops. Reduction in seedling growth under water 
deficiency might be due to suppression of cell expansion and growth that is caused by low turgor pressure (Jaleel et al., 2008). Low water availability during the imbibition phase of germination has been expressed as the main reason for poor seedling emergence (Murillo-Amador et al. 2002). The positive impacts of different seed priming treatments regarding alleviating the detrimental implications of abiotic stresses on plant species at early growth has been reported. In recent investigation, the advantage of seed priming in terms of seedling emergence and growth was more remarkable under lower available water levels. As shown in Table 1, when soil moisture is sufficient $(100 \% \mathrm{FC})$, the differences between primed and non-primed seeds was statistically negligible yet under severe water stress there was a substantial gap between them. However, Farooq et al. (2013) expressed that the better germination start caused by seed priming leads to consequent greater seedling growth under both well watered and water deficit conditions. Seed priming with different compounds including water, urea and $\mathrm{KNO}_{3}$ considerably improves germination and early growth of Chinese cabbage under water stress conditions (Yan, 2015). Tian et al. (2012) also reported that root system of primed plants develops in advance and causes more tolerance against water stress.

\subsection{Seedling Water Status}

Retaining higher cell water potential under water stress leads to higher stomatal conductance (Sellin, 2001), which may promote root performance to uptake water from soil (Chimenti et al., 2006). In our study, higher root length in SA treated samples under 50 and $25 \%$ FC (Table 1) improved the water uptake performance and caused more balanced water relations including RWC. The plants ability to retain higher leaf relative water content under drought stress determines tolerance and sensitivity to drought stress (Sanchez-Rodriguez et al., 2010).

\subsection{Osmolytes Accumulation}

Plant species are capable to accumulate various ranges of organic materials named osmolytes to perform osmotic adjustment and confront osmotic stress. Accumulation of These compounds on the one hand allow plant cells to regulate turgor to uptake water and on the other hand protect cell compartments from the implications of dehydration (Lambers et al., 2006). Osmotic adjustment in order to maintain cells osmotic potential, is a key mechanism to face osmotic stress caused by drought, particularly when drought stress rises gradually (Lipiec et al., 2013). In many cases, it has been reported that there is strong correlation between sugars, trehalose accumulation and drought tolerance in plant species (Bartels \& Sunkar, 2005; Phillips et al., 2002). In our study, the pattern of changes regarding TSS and trehalose content in response to increasing water deficit (regardless priming treatments) was almost similar to GB and proline, yet the reaction to priming treatments especially with SA, was totally different between them. The reaction to water deficit induced by SA priming (greater seedling emergence and growth), was not accompanied with corresponded accumulation of soluble sugars (Figure 1) and trehalose (Figure 2). Unlike TSS and trehalose, the accumulation of proline and GB was significantly increased by SA. As somewhat reported here, there are numerous evidences about proline and glycine betaine role in stress tolerance so it seems that enhanced proline and glycine betaine content resulted from SA priming is associated with greater water deficiency tolerance. The influence of SA on these two osmolytes was greater under higher levels of water deficit and the differences between SA priming and two other treatments were considerably more visible when water deficit intensified. In this respect, Hasegawa et al. (2000) expressed that the ability to perform osmotic adjustment is a key attribute for plant survival under severe osmotic stress. As a matter of fact, proline performs a protective function by either regulating osmotic potential or scavenging reactive oxygen species within plant cells (Hasegawa et al., 2000). Proline accumulation in response to abiotic stresses may alleviate the cytoplasmic acidosis which is necessary to keep balance between $\mathrm{NADP}^{+}$and NADPH which is necessary for plant metabolism (Singh et al., 2015). Our results are in accordance with other reports that cited the impact of drought stress on free proline content, which consequently promotes seed germination and early growth (Krasensky \& Jonak, 2012; Yan, 2015). In case of GB, Zhang and Rue (2014) reported that seed priming with GB, mitigates the inhibitory effect of abiotic stresses on turfgrass species germination. GB roles regarding osmotic adjustment and improving plant tolerance against oxidative stress caused by water deficit were also expressed by other researchers (Ma et al., 2006). Waditee et al. (2005), expressed that introduction of genes involved in GB biosynthesis to Arabidopsis plants induces higher accumulation of GB and increases plant tolerance to abiotic stresses including water deficit. Another study conducted by Wang et al. (2010) clarified that over-accumulation of glycine betaine in a transgenic wheat line, protects thylakoid membrane from harmful consequences of drought/heat stresses and stabilizes the index of unsaturated fatty acids.

\section{Conclusion}

The results of current study showed that seed priming is a useful technique to reduce the limitation caused by water deficit during early stages of smooth vetch growth. In addition, inclusion of salicylic acid to priming 
solution may significantly promote the seedlings response to priming treatment. The impacts of salicylic acid in terms of seedling emergence and early growth were associated with more balanced water status and higher accumulation of proline and glycine betaine as two main osmolytes. Briefly, using seed priming particularly with low concentration of salicylic acid is recommendable for smooth vetch cultivation under rain-fed condition and it may considerably decline the implications of low rainfall during early autumn.

\section{References}

Alonso-Ramırez, A., Rodriguez, D., Reyes, D., Angel Jimenez, J., Nicolas, G., Lopez, M., ... Nicolas, C. (2009). Evidence for a Role of Gibberellins in Salicylic Acid-Modulated Early Plant Responses to Abiotic Stress in Arabidopsis Seeds. Plant Physiology, 150, 1335-1344. https://doi.org/10.1104/pp.109.139352

Bartels, D., \& Sunkar, R. (2005). Drought and Salt Tolerance in Plants. Critical Reviews in Plant Sciences, 24, 23-58. https://doi.org/10.1080/07352680590910410

Bates, L. S., Woldren, R. P., \& Teare, I. D. (1973). Rapid determination of free proline for water stress. Plant and Soil, 39, 205-207. https://doi.org/10.1007/BF00018060

Chen, T. H. H., \& Murata, N. (2002). Enhancement of tolerance of abiotic stress by metabolic engineering of betaines and other compatible solutes. Current Opinion in Plant Biology, 5, 250-257. https://doi.org/ 10.1016/S1369-5266(02)00255-8

Chimenti, C. A., Marcantonio, M., \& Hall, A. J. (2006). Divergent selection for osmotic adjustment results in improved drought tolerance in maize (Zea mays L.) in both early growth and flowering phases. Field Crops Researches, 95, 305-315. https://doi.org/10.1016/j.fcr.2005.04.003

Dabney, S. M., Delgado, J. A., \& Reeves, D. W. (2001). Using winter cover crops to improve soil and water quality. Communications in Soil Science and Plant Analysis, 32, 1221-1250. https://doi.org/10.1081/ CSS-100104110

Farooq, M., Irfan1, M., Aziz, T., Ahmad, I., \& Cheema, S. A. (2013). Seed Priming with Ascorbic Acid Improves Drought Resistance of Wheat. Journal of Agronomy and Crop Science, 199, 12-22. https://doi.org/10.1111/ j.1439-037X.2012.00521.x

Fernandez, O., Béthencourt, L., Quero, A., Sangwan, R. S., \& Clément, C. (2010). Trehalose and plant stress responses: Friend or foe? Trends in Plant Science, 15, 409-417. https://doi.org/10.1016/j.tplants.2010. 04.004

Grieve, C. M., \& Grattan, S. R. (1983). Rapid assay for determination of water soluble quaternary ammonium compounds. Plant Soil, 70, 303-307. https://doi.org/10.1007/BF02374789

Grzesiak, M., Filek, M., Barbasz, A., Kreczmer, B., \& Hartikainen, H. (2013). Relationships between polyamines, ethylene, osmoprotectants and antioxidant enzymes activities in wheat seedlings after short-term PEG- and NaCl-induced stresses. Plant Growth Regulation, 69, 177-189. https://doi.org/10.1007/ s10725-012-9760-9

Hasegawa, P. M., Bressan, R., Zhu, J. K., \& Bohnert, H. J. (2000). Plant cellular and molecular responses to high salinity. Annual Review in Plant Physiology and Plant Molecular Biology, 51, 463-499. https://doi.org/ 10.1146/annurev.arplant.51.1.463

Horvath, E., Szalai, G., \& Janda, T. (2007). Induction of Abiotic Stress Tolerance by Salicylic Acid Signaling. Journal of Plant Growth Regulation, 26, 290-300. https://doi.org/10.1007/s00344-007-9017-4

Hussian, I., Ahmad, R., Farooq, M., Atique, R., \& Amin, M. (2014). Seed priming improves the performance of poor quality wheat seed under drought stress. Applied Science Report, 7(1), 12-18.

Jaleel, C. A., Manivannan, M., Kishorekumar, A., Sankar, B., Gopi, R., Somasundaram, R., \& Panneerselvam, R. (2007). Alterations in osmoregulation, antioxidant enzymes and indole alkaloid levels in Catharanthus roseus exposed to water deficit. Colloids and Surfaces B: Biointerfaces, 59, 150-157. https://doi.org/ 10.1016/j.colsurfb.2007.05.001

Kaya, M. D., Okcu, G., Atak, M., C1kıhı, Y., \& Kolsarıc1, O. (2006). Seed treatments to overcome salt and drought stress during germination in sunflower (Helianthus annuus L.). European Journal of Agronomy, 24(4), 291-295. https://doi.org/10.1016/j.eja.2005.08.001

Krasensky, J., \& Jonak, C. (2012). Drought, salt, and temperature stress-induced metabolic rearrangements and regulatory networks. Journal of Experimental Botany, 63, 1593-1608. https://doi.org/10.1093/jxb/err460 
Lambers, H., Shane, M. W., Cramer, M. D., Pearse, S. J., \& Veneklaas, E. J. (2006). Root structure and functioning for efficient acquisition of phosphorus: Matching morphological and physiological traits. Annals Botany, 98, 693-713. https://doi.org/10.1093/aob/mcl114

Lipiec, J., Doussan, C., Nosalewicz, A., \& Kondracka, K. (2013). Effect of drought and heat stresses on plant growth and yield: A review. International Agrophysics, 27, 463-477. https://doi.org/10.2478/intag2013-0017

Liu, C., Liu, Y., Guo, K., Fan, G., Li, G., \& Zheng, Y. (2011). Effect of drought on pigments, osmotic adjustment, and antioxidant enzymes in six woody plant species in karst of southwestern china. Environmental and Experimental Botany, 71, 174-183. https://doi.org/10.1016/j.envexpbot.2010.11.012

Ma, Q. Q., Wang, W., Li, Y. H., Li, D. Q., \& Zou, Q. (2006). Allevation of photoinhibition in drought-stressed wheat (Triticum aestivum) by foliar-applied glycinebetaine. Journal of Plant Physiology, 163, 165-175. https://doi.org/10.1016/j.jplph.2005.04.023

Murillo-Amador, B., Lopez-Aguilar, R., Kaya, C., Larrinaga, J., \& Flores-Hernandez, A. (2002). Comparative effects of $\mathrm{NaCl}$ and polyethylene glycol on germination, emergence and seedling growth of cowpea. Journal of Agronomy and Crop Science, 188, 235-247. https://doi.org/10.1046/j.1439-037X.2002.00563.X

Parera, C. A., \& Cantliffe, D. J. (1994). Presowing Seed Priming. Horticultural Reviews (University of Florida Journal Series No. R-0327). https://doi.org/10.1002/9780470650561.ch4

Phillips, J. R., Oliver, M. J., \& Bartels, D. (2002). Molecular genetics of desiccation and tolerant systems. In M. Black \& H. Pritchard (Eds.), CAB International Desiccation and Survival in Plants: Drying without dying (pp. 319-341). CAB International. https://doi.org/10.1079/9780851995342.0319

Sanchez-Rodriguez, E. S., Wilhelmi, M. M. R., Cervilla, L. M., Blasco, B., Rios, J. J., Rosales, M. A., ... Ruiz, J. M. (2010). Genotypic differences in some physiological parameters symptomatic for oxidative stress under moderate drought in tomato plants. Plant Science, 178, 30-40. https://doi.org/10.1016/j.plantsci.2009. 10.001

Scholander, R. F., Van Dam, L., \& Scholander, S. I. (1955). Gas exchange in roots of mangroves. American Journal of Botany, 42, 92-98. https://doi.org/10.2307/2438597

Sellin, A. (2001). Hydraulic and stomatal adjustment of Norway spruce trees to environmental stress. Tree Physioogy, 21, 879-888. https://doi.org/10.1093/treephys/21.12-13.879

Shah, J. (2003). The salicylic acid loop in plant defense. Current Opinions in Plant Biology, 6, $365-71$. https://doi.org/10.1016/S1369-5266(03)00058-X

Singh, M., Kumar, J., Singh, S., Singh, V. P., \& Prasad, S. M. (2014). Roles of osmoprotectants in improving salinity and drought tolerance in plants: A review. Reviews in Environmental Science and Bio/Technology, 14, 407-426. https://doi.org/10.1007/s11157-015-9372-8

Szalai, G., Horgosi, S., Soós, V., Majláth, I., Balázs, E., \& Janda, T. (2011). Salicylic acid treatment of pea seeds induces its de novo synthesis. Journal of Plant Physiology, 168, 213-219. https://oi.org/10.1016/ j.jplph.2010.07.029

Tian, F. X., Gong, J. F., Wang, G. P., Wang, G. K., Fan, Z. Y., \& Wang, W. (2012). Improved drought resistance in a wheat stay-green mutant tasgl under field conditions. Biologia Plantarum, 56, 509-515. https://doi.org/10.1007/s10535-012-0049-7

Trevelyan, W. E., \& Harrison, J. S. (1956). Studies on yeast metabolism. 1. The trehalose content of baker's yeast during the anaerobic fermentation. Biochemical Journal, 62, 177-183. https://oi.org/10.1042/ bj0620177b

Varier, A., KuriakoseVari, A., \& Dadlani, M. (2010). The subcellular basis of seed priming. Current Science, 99, 450-456. Retrieved from http://www.jstor.org/stable/24109568

Waditee, R., Bhuiyan, M. N. H., Rai, V., Aoki, K., Tanaka, Y., Hibino, T., ... Takabe, T. (2005). Genes for direct methylation of glycine provide high levels of glycinebetaine and abiotic-stress tolerance in Synechococcus and Arabidopsis. Proceeding of National Academy Science, 102, 1318-1323. https://doi.org/10.1073/pnas. 0409017102

Wang, G. P., Li, F., Zhang, J., Zhao, M. R., Hui, Z., \& Wang, W. (2010). Overaccumulation of glycine betaine enhances tolerance of the photosynthetic apparatus to drought and heat stress in wheat. Photosynthetica, 48, 30-41. https://doi.org/10.1007/s11099-010-0006-7 
Yan, M. (2015). Seed priming stimulate germination and early seedling growth of Chinese cabbage under drought stress. South African Journal of Botany, 99, 88-92. https://doi.org/10.1016/j.sajb.2015.03.195

Zhang, Q., \& Rue, K. (2014). The Effect of Glycine betaine Priming on Seed Germination of Six Turfgrass Species under Drought, Salinity, or Temperature Stress. Horticulture Science, 49(11), 1454-1460.

Zhang, X. Z. (1993). Crop physiology research method (pp. 145-146). Beijing: China Agricultural Press.

\section{Copyrights}

Copyright for this article is retained by the author(s), with first publication rights granted to the journal.

This is an open-access article distributed under the terms and conditions of the Creative Commons Attribution license (http://creativecommons.org/licenses/by/4.0/). 